\title{
The Spanish Morphology in Internet
}

\author{
Octavio Santana Suárez, José Pérez, Francisco Carreras, \\ Zenón José Hernández Figueroa, and Gustavo Rodríguez Rodríguez
}

\author{
Departamento de Informática y Sistemas, \\ Universidad de Las Palmas de Gran Canaria, \\ Campus Universitario de Tafira, \\ 35017 Las Palmas de Gran Canaria, Spain \\ \{OSantana, JPerez, FCarreras, \\ ZHernadez, GRodriguez $\}$ dis.ulpgc.es \\ http://www.gedlc.ulpgc.es
}

\begin{abstract}
This Web service tags morpholexically any Spanish word and it gets the corresponding forms starting from a canonical form and from the flexion asked for. In the verbs, it deals with the simple and compound conjugation, the enclitic pronouns, the flexion of the participle like verbal adjective and the diminutive of the gerund. With the nonverbal forms, this web service considers: gender and number, heteronomy for change of sex, superlative degree, adverbiation and the appreciative derivation. In the tag and in the generation the prefixation is taken into account. It allows the manipulation of morpholexical relationships. It offers a global vision of the behavior and productivity of the Spanish words in the principal processes of formation (sufixation, prefixation, parasinthesis, suppression, regression, zero-modification, apocopation, metathesis and others which are unclassifiable and that generate alternative graphical forms). It includes the principal Spanish lexicographic repertoires. It considers 151103 canonical forms that produce more than 4900000 flexioned and derived forms and about 90000 morpholexical relationships are established.
\end{abstract}

\section{The Spanish Morphology}

As result of the work done by the Group of Data Structures and Computacional Linguistic of the University of Las Palmas de Gran Canaria (http://www.gedlc.ulpgc.es), a Web application has been created able to interpret and to handle with versatility different relevant aspects of the Spanish morphology. The application represents more a form to show the potentiality of a Web System of management of the morphology of the Spanish language than a finalist tool. This system allows its integration in other useful tools for the natural language processing like orthographic correction, advanced search information, text analysers, disambiguousers, lexicographical station, parsers, information extraction, text automatic generation, syntactic correction and extraction of summaries, among other applications, all of them aimed at offering interactive services distributed through Internet. 
The automatized treatment of the Spanish morphology arouses great interest because it constitutes the first touchstone on which to construct any natural language processor and starts the way towards future Web services more specialized in the handling, learning and control of that great human potential -the language.

The available system in the Web tags any Spanish word identifying its canonical form, grammar category and the flexion or derivation that produces it, and is able to produce the corresponding forms from a canonical form and from the flexion or derivation asked for; both the recognition and the generation operate on a same data structure, to cross it in opposite senses implies that the tool works in one or another modality.

In the verbs, it deals with the simple and compound conjugation, the enclitic pronouns, the flexion of the participle like verbal adjective (gender and number) and the diminutive of the gerund. With the nonverbal forms, it considers: the gender and the number in the nouns, adjectives, pronouns and articles; heteronomy by sex change in the nouns; the superlative degree in the adjectives and adverbs; the adverbiation and the superlative adverbiation in the adjectives; the appreciative derivation in the nouns, adjectives and adverbs; the graphical variants in all the grammar categories and the invariant forms such as preposition, conjunctions, exclamations, words of other languages and locutions or phrases. As much in the tag as in the generation the incorporation of prefixes is discretionarily considered.

In addition it allows the recognition, the generation and the manipulation of the morpholexical relations of any word, it includes the recovery of all its lexicogenetic information until arriving at a primitive one, the management and control of the affix in the treatment of its relations, as well as the regularity in the established relation. It provides a global vision of the behavior and productivity of the Spanish words in the main processes of formation (sufixation, prefixation, parasinthesis, suppression, regression, modification-zero, apocopation, metathesis and nonclassifiable others that generate alternative graphical forms).

For the accomplishment of this work, a corpus of Spanish words with the lexicon of different dictionaries has been created: the Diccionario de la Lengua Española de la Real Academia, the Diccionario General de la Lengua Española VOX, the Diccionario de uso del Español de María Moliner, the Gran Diccionario de la Lengua Española de Larousse, the Diccionario de Uso del Español Actual Clave SM, the Diccionario de Sinónimos y Antónimos de Espasa-Calpe, the Diccionario Ideológico de la Lengua Española de Julio Casares and the Diccionario de voces de uso actual directed by Manuel Alvar Ezquerra. From 151103 canonical forms (which include about 15000 proper names and 9000 adjectives coming from participles of verbs not registered in the previous repertoires), they obtain more than 4900000 flexionned and derived forms (without adding the inherent extension to the prefixes and the enclitic pronouns) and around 90000 morpholexical relations are established.

The tagger allows the user to tag any Spanish word -it identifies its canonical form, grammar category and the flexion, derivation and prefix that affects to it. The tag is the first advisable step for the users of the system: on the one hand, it makes the entry flexible when allowing to have access to the rest of the available services without previously having neither morphologic nor grammar knowledge and, on the other 
hand, it identifies without ambiguity the different morphologic interpretations of the inserted form.

The verbal flexioner service allows the user to obtain, from a verb, the conjugation of a simple or composed tense, nonpersonal simple or compound forms, the flexion of the participle as a verbal adjective and the diminutive of the gerund. In addition, it is possible to select from three pull-down lists the valid combinations of one, two or three enclitic pronouns, so that the system incorporates them correctly to the required conjugated forms. The nominal flexioner service allows the user to obtain, from a noun, the changes of gender and number and the appreciative derivation for the selected gender and number. The adjectival flexioner service is similar to the one for nouns, although it adds the specific flexions of the adjectives: the superlative degree, the adverbiation and the superlative adverbiation. The flexioner of other forms service allows the user to obtain, from pronouns, articles, adverbs, prepositions, conjunctions, exclamations, words and expressions from other languages, changes in gender and number and appreciative forms when possible. In addition to the formation rules, the existing irregularities for all flexions are considered.

A important flexibility is the recognition of the existence of prefixes, discretionarily incorporated in the form to tag or to generate. It avoids, therefore, knowledge in this area -as to which prefixes exist in Spanish and which the rules of union and their irregularities are.

\section{The Morpholexical Relations}

The primary target of this service consists of obtaining a set of morpholexical relations between useful Spanish words for applications of processing of the natural language. In a synchronous study, and with the glance put in the automatic treatment of the morphology with computer science means, the formal or theoretical aspects do not have to agree with the strictly linguistic ones. There exist Spanish words that maintain a strong semantic and functional relation -the same that appears in the derivative or prefix level-, and that cannot take derivation or prefixation, although yes a formal relation through other stages in the evolution of the languages exists, that is why it is considered necessary to include them -agua with acuoso, vejiga with vesical, conejo with cunicular. This concept must be restricted to avoid to arrive at the concept of related notion -blanco with albura, sólido with endurecer, niño with pueril-, that is why a criterion of historic-etimologic confluence is applied. It is obvious that, for the speaker, and therefore for computer science acuario, portuario and campanario must be places equally related to agua, puerto and campana. So, it is necessary to pass to another level beyond morphology level, in order to resolve linguistic barriers that they would prevent to treat relations beyond the derivation or the prefixation; the concept of morpholexical relation is extended in this way.

There is an option that facilitates to obtain the set of words morpholexically closer to the given one -its primitive, its derivatives and the derivatives from its primitive. 
Another option serves to obtain the complete family of words with any morpholexical relation. These two possibilities allow in addition their graphical presentation.

Due to any Spanish word is admited as input by the morpholexical relations service, the request is previously treated by the tagger in order to apply the adequate relations on the canonical forms. If the entry comes from more than one canonical form with relations, the requested relations for each canonical form are obtained.

\section{References}

1. Alsina, R.: Todos los Verbos Castellanos Conjugados. 17th edn. Teide, Barcelona (1990)

2. Alvar Ezquerra, M.: La formación de palabras en español. 5th edn. Arco/Libros, Madrid (2002)

3. Alvar Ezquerra, M.: Nuevo diccionario de voces de uso actual. Arco/Libros, Madrid (2003)

4. Carreras, F.: Sistema Computacional de Gestión Morfológica del Español (SCOGEME). $\mathrm{Ph}$. Degree Thesis directed by O. Santana and J. Pérez, Universidad de Las Palmas de Gran Canaria (2002)

5. Casares, J.: Diccionario Ideológico de la Lengua Española. 2nd edn. Gustavo Gili, Barcelona (1990)

6. Corripio Pérez, F.: Diccionario Práctico. Incorrecciones: Dudas y Norma Gramatical. Larousse Planeta, Barcelona (1995)

7. Diccionario de la Lengua Española. Edición electrónica. Electronic edn. 21.1.0, Real Academia Española and Espasa Calpe, Madrid (1995)

8. Diccionario de Uso del Español Actual. Clave. Electronic edition, SM, Madrid (1997)

9. Diccionario de Uso del Español de María Moliner. 2nd edn. Electronic edn., Gredos, Madrid (2001)

10. Diccionario General de la Lengua Española Vox. Electronic edn. Biblograf, Barcelona (1997)

11. Gran Diccionario de la Lengua Española. Larousse Planeta, Barcelona (1996)

12. Gran Diccionario de Sinónimos y Antónimos. 4th edn. Espasa Calpe, Madrid (1991)

13. Gómez Torrego, L.: Manual de Español Correcto, 10th edn. Arco/Libros, Madrid, (2000)

14. Real Academia Española: Esbozo de una nueva gramática de la lengua española. 1st edn. Espasa Calpe, Madrid (1989)

15. Santana, O., Carreras, F., Hernández, Z., Pérez, J., Rodríguez, G.: Manual de la conjugación del español. 12790 verbos conjugados. Arco/Libros, Madrid (2002)

16. Santana, O., Pérez, J., Carreras, F., Duque, J., Hernández, Z., Rodríguez, G.: FLANOM: Flexionador y lematizador automático de formas nominales. Lingüística Española Actual, Vol. XXI-2, Arco/Libros, (1999) 253-297

17. Santana, O., Pérez, J., Hernández, Z., Carreras, F., Rodríguez, G.: FLAVER: Flexionador y lematizador automático de formas verbales. Lingüística Española Actual, Vol. XIX-2, Arco/Libros, Madrid (1997) 229-282

18. Santana, O.; Pérez, J.; Losada, L.: Generación automática de respuestas en análisis morfológico. Estudios de lingüística, Universidad de Alicante, Vol. 14, (2000) 245-257

19. Seco, M.: Diccionario de dudas y dificultades de la lengua española. 9th edn. Espasa Calpe, Madrid (1991) 